\title{
Intellectual Capital and Value Creation Process in Family Firm: A New Combined Model
}

\author{
Francesco Agliata ${ }^{1, ~ *, ~ D a n i l o ~ T u c c i l l o ~}{ }^{1}$, Andrea Rey ${ }^{2}$, Fabiana Roberto ${ }^{2}$ \\ ${ }^{1}$ Department of Economics, University of Campania L. Vanvitelli, Capua (Caserta), Italy \\ ${ }^{2}$ Department of Economics, Management, Institutions, University of Naples Federico II, Naples, Italy
}

\section{Email address:}

f.agliata@unicampania.it (F. Agliata), danilo.tuccillo@unicampania.it (D. Tuccillo), andrea.rey@unina.it (A. Rey),

fabiana.roberto@unina.it (F. Roberto)

${ }^{*}$ Corresponding author

\section{To cite this article:}

Francesco Agliata, Danilo Tuccillo, Andrea Rey, Fabiana Roberto. Intellectual Capital and Value Creation Process in Family Firm: A New Combined Model. Journal of Human Resource Management. Vol. 7, No. 4, 2019, pp. 108-119. doi: 10.11648/j.jhrm.20190704.15

Received: October 25, 2019; Accepted: November 18, 2019; Published: November 22, 2019

\begin{abstract}
The purpose of this paper is to define a new combined model of business valuation for family firm, considering the implications of IC. The role of the family component in business valuation is condensed into the continuity of a transgenerational perspective. The question appears to be centred on the consistency of the familiness link with respect to the economic entity. In other words, it becomes essential to understand the provisional character of the proactive action of family members on business performance levels. After having discussed some of critical theoretical opinions on the peculiar aspects of family business - with particular attention to the relationship between the contribution of cognitive resources inferable from the familiness in the company management and the propensity to create value by the company itself - the aim is to find the most appropriate method to enhance the specificity of the family business and express the size of the equity value in a neutral and objective manner. The methodology is deductive; the integrated model is structured starting from the general framework of business valuation and then proceeds with its adaptation to familiness, intended as a particular attestation of IC. In this way, a new integrated model is made available for a subsequent step of empirical implementation and validation through its application in a family organization. The main advantage of this model is the ability to measure and manage IC and financial/non-financial performance. The added value of this work will enrich the academic literature regarding IC measurement systems in family firms; it also provides an original integrated model that is able to exhibit the advantages highlighted above.
\end{abstract}

Keywords: Familiness, Intellectual Capital, Performance Measurement System, Financial Statements, Family Firm

\section{Introduction}

The implications of a firm's family component for creating value are considerable; they expand the observation beyond the simple presence of family members within the ownership structure and focus on their ability to instil in the operational management the idea that 'family nature' is a certification of a specific brand and a source of competitive advantage [1,2].

Discordant views have emerged in the literature on the various issues concerning family business, on whether characteristic business elements have been analyzed, or on the interrelations that exist between family and business [3]. Concerning the effects on the corporate performance levels, the potential impact of the so-called 'familiness' in the life of a firm from a future perspective is interesting to examine [4, 5]. Assuming that the influence of familiness on the historical, current, and future income levels are accepted, then opinions about its relevance to the firm's equity value will be justifiable, helping distinguish this last concept from the broader business strategic value $[6,7]$.

In this scenario, adequate performance measurement methods will have to be identified; these will be necessary to facilitate the implementation of the strategies and improve the levels of the achievable economic results [8]. Everything appears instrumental in estimating the intangible resources, included in the broader concept of intellectual capital; the IC will be the primary source of value creation and sustainable competitive advantage for the examined economic entities $[9,10]$. 
Among the various business valuation methods existing in the literature and usable in professional practice, the purpose of this work is to identify the suitable method for highlighting or extrapolating the specific contribution of familiarity to achieve a competitive business advantage.

Our proposition is: How we can evaluate a family business limited to the family characteristics transferable with the company?

This work is structured as follows: the second section aims to recognize the familiness as a peculiar form of intellectual capital in the family business. The third section focuses on the deductive methodology of work and on recognizing the income and capital impact of familiness and its recognition in the financial statements. The fourth section discusses the incidence of family component on corporate performance levels. The fifth section concentrates on the problems of measuring the business equity value in particular for the family firm. The final section proposes an ad hoc method for measuring equity value in family firm.

\section{Intellectual Capital in the Family Business: Theoretical Background}

The phenomenon of family business has long influenced the entrepreneurial realities in many ways. Such peculiarity can be found in the most varied organizational forms of the firm, both observing the legal form adopted and ascertaining the business developed and the size achieved. Therefore, it can be assumed that there are different types of family business in terms of size, production value, ownership model, and governance [11].

It can be assumed that the key variable for obtaining a competitive advantage is not the material resources available in an organization but rather a combination of methods and synergies that the same resources are able to establish in the phase of business activity. The emerging basic theme would consist of the so-called 'tacit personal knowledge' as an intangible and strategic factor for obtaining a competitive advantage. However, knowledge is considered a critical success factor and therefore a resource-generating equity value, if that is the ability to obtain the necessary information for taking strategic decisions [12].

In family firms, the objectives pursued by the management is change; the priority of the family may involve considering and conceiving of the organization as a source of financial well-being and a family identity tool to be transmitted over time. In the past, the organization was considered a means of realizing the professional and economic development of the management; it was also considered a privileged form of investment from which to expect a satisfactory return for the risk taken [13].

Such a conceptual approach tends to favour a familyoriented approach rather than being simplistically business oriented. The interest of management may not be confined to profit maximization but extend to qualitative aspects $[14,15]$. This illustrates the significance of the elements perceived as fundamental by the managing family; however, they could prove to be irrelevant in a scenario of generational transition or in the case of acquisition by an unfamiliar subject.

The family has mainly non-economic institutional purposes, attributable to the emotional, social, religious, biological, and environmental spheres, which may inevitably assume a conditioning role in the company's strategic choices (Socio-Emotional Wealth Theory - SEW). In fact, the family business can be understood as an entrepreneurial attestation, where the intensity of relations with one or a few families of reference becomes pre-eminent $[16,17]$.

However, in a traditional approach, the business institutional aims do not always coincide with the cultural values of the family institution. Instead, in the family business, the so-called phenomenon of 'institutional overlap' between the firm and family emerges. More important, the inclusive effect of family values in business life will in particular concern governance, strategic orientation, human resources management, and financial management [18, 19].

A further consideration would concern the critical analysis of the influence of familiness on the life of the enterprise; in other words, one wonders about the outcomes and the areas affected by this overlap. In this regard, in recent studies, family relationship that can only be linked to two specific management aspects seems outdated: the financing through the use of equity and the corporate governance activity [20].

In international studies, an idea that borders on the company mission has spread [21, 22]. In particular, in the Resource-based View Theory, the concept of familiness has been placed, centre stage and understood as a unique set of tangible and intangible resources, such as family businesses, which originate in the interrelation among the company systems, the family systems, and the individual behaviour of the family members $[5,23]$.

The idea of the three levels of ownership, governance, and management of the company are indicators of 'conditioning'. Hence, the idea that a majority (or significant portion) of risk capital must be owned by a family or the presence of family members in the governing bodies is sufficient to ensure the control of strategic decisions appears outdated. In this case, however, the results of family behaviour are directly observed; the presence of the family members in the company management is not indispensable, mainly because the influence of family interference into the company goals becomes essential [24].

Qualitative and quantitative studies that investigate the relationship between family involvement and performance strongly confirm the above-mentioned considerations. They highlight the opportunity to distinguish the appropriate moderating and/or mediating variables for interpreting the family involvement-performance relationship in order to clarify and capture the generally intangible aspects of family interference capture with profound impact on the achievable economic results [25].

Theoretical assertions based on empirical evidence have emerged, which emphasize the lack of correlation between formal participation and business results. Thus, the need to 
overcome the structural approach was born, and the awareness matured to welcome the intention-based approach, thus putting a great emphasis on cognitive and behavioural aspects $[26,6]$.

Moreover, in family firms, in addition to various problems just outlined, there are other problems related to the representation of financial statements, which include (as far as legal) both values attributable to economic activity and those ascribable to family dynamics (see the scheme summary in Figure 1).

Table 1. Institutional Overlap: Opacity of the financial statements.

\begin{tabular}{lll}
\hline & Family & Firm \\
\hline \multirow{3}{*}{ Income Statement } & Lower net income: & Higher net income: \\
& Higher family costs; & Absence of family costs; \\
& Higher manager-owner fees. & Lower manager fees. \\
& Properties available to the firm: & Properties available to the firm: \\
& Does not contribute to the firm's production activity; & Contribute to the firm's production activity; \\
Balance Sheet & Owned by the family. & Owned by the family. \\
& Among the items of equity: almost never "dividends to be & Among the items of equity: dividends to be distributed. \\
\hline
\end{tabular}

Source: Own elaboration.

Therefore, after having ascertained and agreed on the need to translate the variable familiness into cognitive and learning terms, it must be preserved over time, so that familiness can be considered relevant to the business valuation. In fact, only if this intangible resource is preserved in the successor relationships, can it be considered relevant to the financial and income purposes within the family business organization. In other words, a family business oriented towards the creation of value must be attentive to the growth of the firm's wealth and also to the possibility of transferring the created value in favour of subsequent generations [27, 28].

Consequently, the continuity of the family aspect, considered by many scholars as a strategic condition for safeguarding the competitive position achieved in the competitive arena [29, 30], is also acceptable in the generational transition, especially when the entrepreneur:

1. Is aware of the opportunity to transfer the acquired and tacit knowledge and of the relationships ascribable to his/her person, so that they become distinctive elements of the company and not of the person managing it;

2. Manages to distinguish the elements of advantage and the risk factors emanating from the figure of the entrepreneur, so that they can be manageable and countered by other distinct economic subjects [31,32].

\section{The Contribution of Familiness to Value Creation: Methodology}

The role of the family component in business valuation is condensed into the continuity of a trans-generational perspective. The question appears to be centred on the consistency of the familiness link with respect to the economic entity. In other words, it becomes essential to understand the provisional character of the proactive action of family members on business performance levels [33, 34].

The continuity of these skills, which can be defined as knowledge and operational skills-generally non-structural, formed in the enterprise, and the result of an internal learning process - makes them relevant from an accounting point of view as intangible resources that are internally originated. On the other hand, if there is a transitory nature of family characteristics linked to the founder's figure, the situation will change substantially, mainly because the contribution of familiarity will be temporally predefined and limited, and its contribution to business valuation will be delimited to the mere analysis of the implications of historical income results $[35,36]$.

Hence, the different accounting situations are ascertainable in relation to the different imagined considerations of departure. In the first hypothesis, there will be a recognition of such intangibles - similarly to what happens to intellectual capital [37] through the signing up of a specific asset in the balance sheet, which is economically justifiable by the link deriving from the synergies/behaviour of family members with obtainable prospective income results [38].

The crucial element of the family aspect initially resides in the drafting phase of the financial statements and subsequently in the quantitative determination of its propensity to create value in the future. The ratio underlying the accounting recording of an intangible asset is based on the belief that, after having ascertained its value-when it is revealed for consideration - the quality of the amount registered must be tested periodically by comparing it with the corresponding recoverable value. Thus, the problem can be framed by addressing the capital aspect of the company and its ability to earn income.

Furthermore, the question arises about the accounting outcomes, deriving from the second theoretical assumption, where the lack of knowledge continuity perspective, which would then remain anchored to the founder, would result in the loss of these acquired tacit distinctive capacities; this is because they are generally enclosed in the figure of the entrepreneur as the primary source of knowledge. In fact, if the knowledge cannot be formalized through the dissemination and creation of appropriate routine behaviours or specific legal cases, the latter cannot be considered available and appropriable assets; consequently, not even its resultant accounting recognition of specific assets will be conceivable. Moreover, in such circumstances, there are advocates of the opportunity to recognize a specific liability 
as evidence of reduction in the value of company assets [39].

The hypothesis is that the intellectual capital will be detectable only if it can be formalized and structured in specific financial statement items (goodwill and/or other assets). For example, the constituent components of the socalled 'structural capital' include patent, brand, copyright as well as the systems of Business Intelligence, ICT, quality management processes, and planning and strategy management processes [40].

On the other hand, a tacit familiness should be assumed as a particular manifestation of intellectual capital, originating from the transitory impact of the family effect on the life of the enterprise. In this scenario, the potential nontransferability of cognitive resources will result in the nonrecognition of the assets, contravening the thesis of those who alternatively considered it necessary to record a liability [4].

In a business valuation process for a family business, the basic reasoning is that the transitory influence of these particular cognitive resources concerning family interference in the life of the firm must be neutralized without the use of a passive item [9].

A liability is not to be recorded, mainly because there is no obligation to be fulfilled in the future. Further, the writing of a rectification post of any asset as a specific manifestation of the intellectual capital in the business family, imputable to such familiarity, is not even admissible. The definitive answer to these various dissertations consists of admitting the exclusion in the financial statements of such resources; it also consists of determining the quantitative dimension of the future income results net of the potentials concerning the family components, which, in the past, used to be key to conditioning the historical income results.

To summarize this discussion so far, familiarity can be understood as a specific and particular component of the cognitive capital available to the company; this intangible resource can become relevant in the process of creation of business value, only if it will be durably endorsed by the company and not by the person managing it, even if they originated through the action/behaviour of the same manager. Another study can help deepen our understanding of the best management methods, with a view to preserving this acquired intellectual capital and making it a non-transitory component. This aspect becomes strategic and crucial for company survival and the maintenance of competitive positions over time $[8,41]$.

The concept of value creation for a family business is based on (a) the trans-generational perspective, (b) the longterm vision of the implemented investment strategies, and (c) a perception of growth that does not end with the increase in the equity value but includes a cultural and social development in line with the cultural values of the family. From the 'cultural approach', as an interpretative model of the business family phenomenon, two distinct questions will emerge [42].

On the one hand, in an in-depth observation of family business from an income perspective, scholars consider a multidimensional enlargement of performance to take account of the socio-cultural connotation. Obviously, the main difficulty will be the identification of specific indices, integrated with each other in a system. To this can be added the construction of an appropriate strategic map, which demonstrates the relationships among the different qualitative-quantitative aspects and their potential impact on income results [43]. On the other hand, a recurring problem in the family business studies emerges, which concern the identification of the methods used to ensure the persistence/durability of family effect over time. The doctrinal debate has translated this problem into the need to ensure the conservation of entrepreneurial knowledge, implementing the cognitive experience, and contextualizing it at the company level.

This last aspect will be feasible if the knowledge of the founder:

1. Will consolidate and stabilize among the various subjects, operating internally to the economic entity. Even in the case of generational successions, they will represent the human capital available to the firm (personal or individual knowledge) [44];

2. Will be acquired through the diffusion of behaviours, which will be repeated over time by subjects different from those already operating within the organization. On the other hand, they are now considered to be established company practices, habits, customs, or routines (organizational capital) [45];

3. Will be outsourced through the establishment of relational connections with various social and competitive interlocutors (relational knowledge) [46].

In conclusion, the familiness can be considered a particular figure or attestation of intellectual capital. It takes on specific characterizations in relation to particular applicative fields and, in order to be considered valid for the measurement of the enterprise's actual value, is to be preserved over time. Afterwards, the accounting representation in certain assets will depend on the characteristics of the intangible resources (legal autonomy and transferability of the resource) [47].

\section{Relations Between Family Business and Performance}

In various studies in the literature, especially in the empirical ones, the strategic survey variable mentioned at the beginning is usually due to the 'presence' of the family in the property (i.e., FIO or family involvement in ownership); this would be an objective parameter and a valid indicator of family involvement in company dynamics [48]. However, in the case of an observation on the degree of participation in company management by family members and their involvement in governance systems (i.e., FIM or family involvement in management) where the scenario can change substantially and become much more complex, it would be necessary to homogenize, parameterize, and relativize, where possible, the various situations investigated. 
The preliminary results that interpret family business as a particular successful business solution base their convictions mainly on the following strengths $[49,50]$ :

1. The direct involvement of family members in the dynamics of the organization would push towards an overlap of interests between the owners and managers, thus limiting any opportunistic behaviour and reducing agency costs, as negative components of income linked to the control of the enterprise [51];

2. The long-term family horizon would lead to a long-term strategic-corporate vision by management, thus encouraging solid investment policies capable of sustaining value creation over time [52];

3. The long-term horizon of the family would cause the adoption of conservative choices suitable to preserve and pass on the company in healthy conditions to the following generations. Hence, the possibility of admitting non-speculative behaviour rather than instrumental to guaranteeing value creation over time would derive [53];

4. The strong link between firm and family would facilitate the monitoring of the behaviours assumed and the results obtained within the economic entity; this would be brought about as a degree of knowledge of the more detailed company reality is conceived, resulting from the evident position of favour assumed by the family [54];

5. Finally, moving beyond the simplistic assumption of the presence of family members within the ownership structure and rather focusing on their ability to instil in the operational management the idea of 'family nature' in business as an attestation of a specific brand and a source of competitive advantage; the propensity of family business to receive reputational advantages related to the development of a consolidated relational capital made available to the company by the family is assumed.

Nevertheless, various weaknesses of family businesses can be found; the latter have often been used, as justifying elements, in the empirical studies where negative economic trends have emerged, compared to the unfamiliar benchmarks operating in the same sector $[55,56]$.

In this case, the discussion concerns the 'constrictive familiness', meaning that, in the absence of proper management of family resources, the latter would become a source of 'encumbrance' for the enterprise itself [1]:

1. The family would be able to adopt a conditional risk approach, as a consequence of the pursuit of nonmonetary objectives (for example tradition, integrity of reputation, cohesion of family members, independence from financiers outside the family, and control over the company). Investment decisions can therefore be made, not always with a view to maximizing the equity value;

2. A lack of real awareness or limited perception of opportunity costs. These costs on the one hand involve the development of self-financing policies and on the other hand would expose the company to investments in riskier sectors. Family capital can be considered an example of patient capital and it does not claim to be remunerated [57].

3. The tendency to place the family members of the entrepreneur in the command posts, even in view of limited managerial skills or unsatisfactory results achieved, as a means of having total control over the established economic entity. Unfortunately, this concentration process denies the entry of professional and more competent managers and limits the potential for development of the firm [58];

4. The possible small family assets resulting from a lack of inclination to introduce new owners and therefore potential decision-makers in decision-making management. Moreover, in this regard, the low level of capitalization can be justified by ownership decisions to obtain financial resources in the form of loan capital; the inclusion in the taxable income of the consequent interest expense will allow obtaining tax benefits [59].

Thus, theoretically the familiarity is not, in an unquestioned way, a source of competitive advantage, capable of guaranteeing higher levels of performance than other non-family subjects. Rather, there is a strong conditioning by family attributes to influence the company's propensity to earn income, although weighted by the belief that they may be able to potentially affect both the positive and the negative [4].

Similar statements supported by numerous empirical studies demonstrate that, theoretically, it is not possible to assure the existence of a single conceptual approach regarding the sign of the evident correlation between family business and performance. In other words, after having considered familiness, as a particular manifestation of intellectual capital, success will be based on the propensity of the managerial class to strategically and advantageously manage these cognitive resources for the company $[3,60$, 61].

The following figure shows the specific management phase of generational passage, showing the risk and success factors combined with the transfer of knowledge attributable to familiarity. In fact, knowledge is the main source of competitive advantage for firms, and the survival/maintenance of the competitive positions reached is based on the ability to put in place valid procedures for the transfer and subsequent management of knowledge from the entrepreneur to the successor.

Table 2. The influential aspects of knowledge transfer in business successions.

\begin{tabular}{ll}
\hline & Personal motivation \\
Family structure & Level of IC held \\
& Supervisory, coordination and management skills \\
& Awareness of success \\
\hline
\end{tabular}




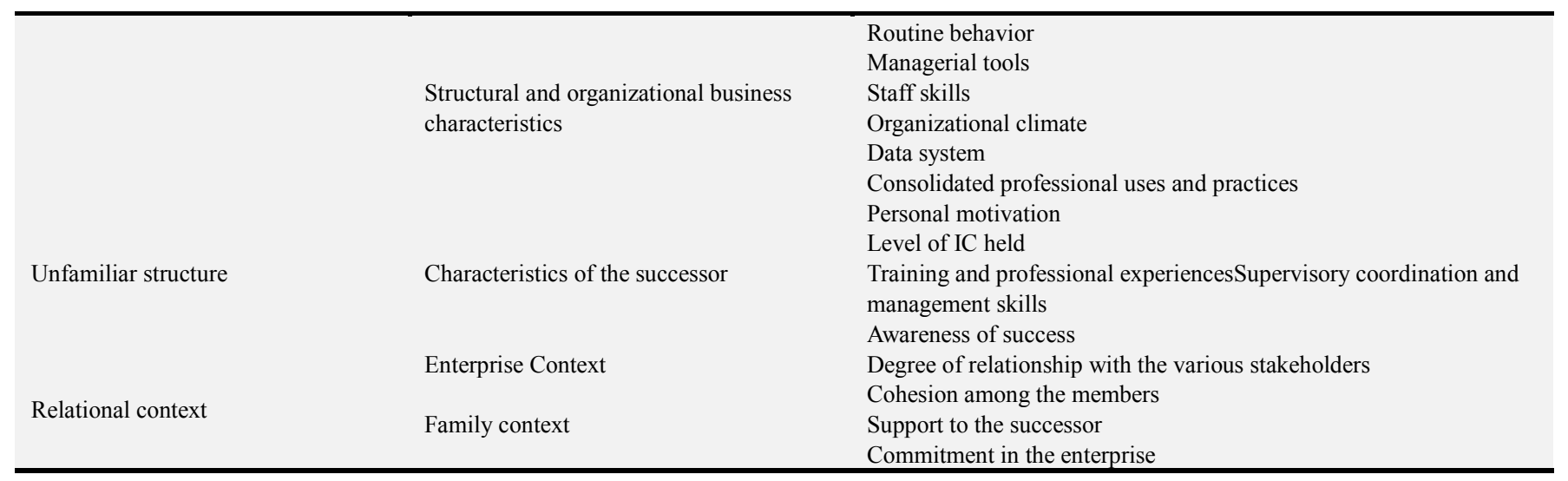

\section{Characteristic Aspects and Critical Issues in the Measurement of Family Firm's Equity Value}

Concerning the measurement of equity value, in any organization, the value must be taken into account from a 'general' and 'abstract' perspective. The measurement must take place from the perspective of a generic rational investor who is free and aware and consider only the resources related to the firm. The conditions and the interests of the contracting parties involved in the negotiation must be ignored. In this case, the requirement of neutrality/equity is proof of independence of the evaluator.

Therefore, considering the independence from any subjective and potential measurements, the firm must be detected in the current economic conditions and according to the pre-planned strategic programmes. The main intent is to make the value of the firm independent from the so-called 'non-appropriable' factors in a hypothetical perspective of management continuity and on the basis of expected income flows, determinable in relation to already acquired income capacities.

These aspects support the hypothesis of corrective intervention and highlight the question of evaluative reliability. To cancel the subjective component deriving from the inclusion in the prospective income flows of the entrepreneurial contribution, it is necessary to neutralize the accounting interventions to decrease the uncertainty and sensitivity of the estimate.

Scientific research on the best methodological solutions in use is aimed at the methods that are able to counteract such problems, including all the various cases of the business valuation. In fact, there is no universally recognized optimal method applicable to different cases; however, the choice must take into account various elements, such as the purpose of the evaluation, the scope of application, the sector of belonging, the operating economic context, and the information available to the expert.

Moreover, this value neutralization procedure justifies the recurrent gap between equity value and agreed exchange price. The latter in fact is the result of negotiations among subjects of different perspectives or business needs, which justify different perceptions of value.

In family firms, a series of critical issues guided by quantitative measurements to familiness can be found. For example, in this characteristic company typology, probably the primary limit that can be ascertained will derive from the partiality of obtainable information from the general accounting documents drawn up in compliance with the civil law.

This argument has constituted for many scholars the element to discriminate some estimative techniques in favour of others. The writer, however, believes that these limits affect the various methods in use. In particular, the 'contamination of familism' within the financial statements can cause distortions in the consequent accounting representation, regardless of the application context [62].

The need to make a larger number of adjustments in the particular area of family businesses for the normalization of the income configuration is not questioned. However, this would not support the preference of alternative methods of the so-called financial- and income-based approaches. Nevertheless, even the adoption of asset-based methods require specific adjustments arising from the interference of family interests, for example the availability to the firm of the properties of promiscuous use, that is intended entirely for business production.

Therefore, an approach that would admit the cognitive superiority of the more easily calculable methods would provoke a simplistic conceptual forcing and constitute a mere choice of convenience. On the other hand, the recognition of the opportunity or predilection for a specific technique is allowed, especially if it is in keeping with the peculiarities ascertainable in the specific type of business organization observed.

Having said that, in this specific case, the prevailing doctrine recognizes the strategic advantages added to the business valuation. In fact, it asserts that in the typical family business scenario, the business valuation would represent a useful tool to guide management decisions, freeing them from merely familiar objectives. The identification of a measure released from the non-transferable and unusable economic forces by subjects other than the entrepreneur 
would broaden the managerial strategic orientations.

Moving on to examine more precisely the technicalprocedural phase of measuring the equity value, the salient point of discussion concentrates on identifying and ascertaining the methods for recording in the financial statements the intangible resources that refer to family interference in the life of the firm and then ascertaining its contribution to business valuation. First, the so-called 'appropriable' assets will have to be recognized, since in the future they will find a distinct accounting expression in the assets re-expressed at current values, and subsequently their prospective profitability within the company must be ascertained, since the writer favours the meaning that capital, rather than a fund of different values - albeit coordinatedshould be understood as a 'single value, resulting from the capitalization of future income'.

The family contribution can be attributed to the mere contribution of material assets or to the cognitive contribution through the attribution of new skills deriving from the family behaviours or actions, as a typical attestation of familiness. For the first type of resources, there is generally an active reference market suitable to express a presumable realizable value, from which to deduct a specific amount to be recorded in the financial statements. Instead, for the various groups of intangible resources, a singular market that is recognizable and active is not always identifiable.

Therefore, with regard to the material resources conferred, particular problems relating to the specific nature of the transferring subject are not found. They do not fall within the concept of familiarity in the strict sense and are intended as singular economic forces available to the firm, transmissible in the event of a trans-generational transition, or a mere transfer to third parties.

On the contrary, the pertinent issue of family businesses concerns the second specific type of intangible resources; in particular, three distinct classes of intangible components are distinguishable:

1. The first concerns the so-called intangible components intrinsic to the presence of family members and summarized in the non-transferable intellectual capital of the entrepreneur. Consequently, this class of components is not 'appropriated' to the firm, such as the commitment, the accumulated experience, the intuition, the singular managerial skills, and the dedication of the owner and his family;

2. The second class, however, concerns the intangibles that interfere with family members and descendants of the intellectual capital of the entrepreneur, consolidated at company level and therefore 'appropriable'. The latter are the so-called internally originated goodwill factors, relating to marketing, technology, human capital, relational capital, etc. They are not legally identifiable and transferable individually, but they are joined as synergistic forces in the goodwill item;

3. The third class refers to the identifiable and separable assets, although these assets originated as a result of family interference at company level, they have reached a stage of autonomy and separability from the family and the company itself. For example, the latter include the brand, the patents, the distribution network, the customer portfolio, etc. They will represent the only prototype in which the presence of a specific active reference market will be perceptible to appreciate the corresponding confining balance items, such as intangible assets, normally included in the item 'intangible fixed assets' [63].

After declaring the distinct classes of membership for the various intangible resources, at this point some critical observations on the accounting and quantitative measurement detection, useful to arrive at the calculation of the equity value, are synthesizable.

In relation to the first type of the listed resource, the assets will remain with the initial manager and therefore will not receive any consideration when drawing up the prospectus documents of the financial statements and estimating the equity value. The question appears valid because these assets represent that part of the intellectual capital, owned by the entrepreneurial subject, that is definitively separated from the company when a transfer of the economic entity is made [64].

Naturally, in this scenario, when estimating the future performance levels, the procedures of adequate adjustment must be used. The lack of contribution from these assets in the balance sheet is evident; however, the historical income results have recently been presented as a result of the propensity to create value in the organization by these intangibles. Therefore, at the time of business valuation, the need to resort to the direction of appropriate procedures, aimed at normalizing future incomes, is assumable, so that neutralization from the future business attitude to produce added value by these intrinsic activities will be obtained [65].

The second class of resources will not be present in the historical balance sheets; however, their future appearance in the patrimonial area is desirable in a business transfer. In this case, the factors will flow indistinctly with goodwill. On the other hand, the income impact should remain unchanged and, therefore, accounting corrections cannot be assumed, mainly because the factors in question, being consolidated in a systematic way, will continue to participate in the production activity constantly and regardless of the ownership and governance dynamics [63].

Finally, as for the last set of intangibles, in such a situation no particular corrective interventions can be envisioned. The resources in question, due to their nature of transferability and legal identifiability, will receive appropriate accounting representation in the balance sheet both in the historical and prospective tables. Furthermore, normalization operations of future incomes will not be required, since they can be considered the regular continuation of the historical ones. In conclusion, the same accounting treatment reserved for the tangible assets conferred by the family can be anticipated [31]. 


\section{Conclusions: An Integrated New Model}

After having discussed some of critical theoretical opinions on the peculiar aspects of family business-with particular attention to the relationship between the contribution of cognitive resources inferable from the familiness in the company management and the propensity to create value by the company itself - the aim is to find the most appropriate method to enhance the specificity of the family business and express the size of the equity value in a neutral and objective manner.

First, the discussion assumes that familiness inevitably conditions at the asset and income level, both positively and negatively, the life of a business organization. The effects of such familiarity must be ascertained in its survival over time, even in the case of transnational succession and appropriate measures to neutralize the interferences not appropriate to the economic entity will have to be adopted. This last aspect supports the need to perform income normalization operations. In fact, the loss of some family resources, which are not permanently anchored to the company, will certainly cause accounting outcomes on future performance levels, which consequently will not be considered as a prospective and continuous projection of historical results [66].

On the other hand, countless studies have debated the desirable accounting interventions and have emphasized how such corrective actions affect the information quality of the measure appreciated. Specific treatments of the peculiar 'unreachable' exchange flows between company and family must be identified, which influence the final quantitative results.

Without intending to discuss the various emerging accounting issues, the salient ones can be summarized as assets for family use, remuneration of family work, interest expense relating to financial debts towards shareholders, tax component, selection of a discounting rate of the emotional component, etc. These transactions are aimed at expressing the potential real value over time of the company regardless of the manager. The adjustment procedures will also affect the heritage assets, even if with less significant interventions; the actions will be aimed at detecting the balance sheet of those tangible assets for family use and ensuring the nonregistration of all those intangibles, which are not suitable for the company, with the exception of assets included in the goodwill item, which have been calculated, inductively and residually, only after the business valuation and of those assets having legal autonomy and therefore transferable and independent from the family [67].

It is useful to understand the peculiar accounting criticalities, caused by the particular characteristics of the family business. Favouring a business valuation method, based on the lower complexity of technical operations, would be a serious mistake. On the contrary, the procedure suitable for expressing in the best way the specific features included in family businesses must be chosen in order to show their contribution in calculating actual value [68].
Such an approach would lead to a partial, limited, and inadequate appreciation to express the economic-prospective potential of the firm. There is no doubt about the complexity of the allowable corrections and the feasible, practicable modifications. Nevertheless, such re-adjustments/reelaboration of values included in the formulas do not distort the theoretical validity of the models themselves [69].

That said, three distinct approaches are identifiable: dynamic, static, and empirical. The first approach favours the perspective to generate future income or cash flows, as the main variable to appreciate the business value. The second approach focuses on the prospect of capital consistency until it is created rather than on the ability to increase this wealth over time. Finally, the third approach is based on the establishment of an empirical comparison among the results of similar transactions.

Furthermore, with a view to identifying the most appropriate estimation model, hoping for the synthesis among the various types of approaches existing in relation to their degree of rationality and elaborative complexity, the following summary figure is presented:

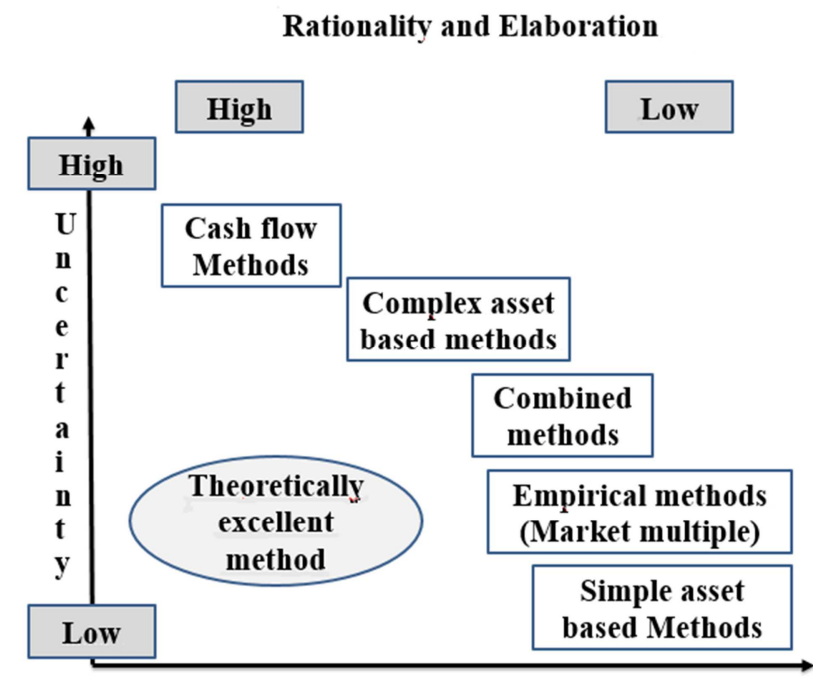

Source: Elaborated starting form: Riva, (2008: 26).

Figure 1. The summary of various models existing.

The obvious inadequacy of the empirical method emerges, since it appears to be free from the components referable to the family business. Rather, the aforementioned method depends strictly on the singular situation appreciated, considering the contractual strength of the negotiating parties. The resulting value may be variable in relation to the specific circumstance investigated and, consequently, this method cannot be considered of primary importance in the business valuation process. The information coming from the empirical evidence cannot be generalized, since the exchange prices, deriving from the market, will usually be affected by the distinct subjective characteristics ascribable to the contracting parties and to the particular family aspects [70].

In fact, the market multiple method is not based on solid conceptual and methodological supports but on sets of 
empirical rules inspired by the market and based on the different opinions present in the sector, where the investigated firm operates. Therefore, the latter can act as a tool for the formation of the market price or a starting point for more sophisticated and complex valuation techniques.

In contrast, the rational methods are based on values of financial statements, illustrating that the actual value of a firm derives mainly from the available wealth and the propensity to increase this wealth over time. However, in the family business, the scholars evaluate the opportunity to prefer methodologies for discounting income/financial flows or to prefer asset-based approaches.

In this regard, the need to promote techniques that are capable of grasping the essence of familiarity to create value emerges and therefore, the adoption, which confines the cognitive inquiry merely to the values of capital or income, would appear limited. The interference of familiness on the company life affects the amount of balance sheet items, contaminated by the resources originating from the implementation within the company of those cognitive skills variously manifested as well as the attitude of the company to achieve positive income results [71].

Consequently, starting from these preliminary hypotheses, the present work aims at identifying the evaluative approaches that are able to juxtapose and combine the various items of financial statements on which the family contribution is visible or perceivable. In other words, the writer supports the adoption of the so-called 'combined methodologies', to be able to simultaneously capture the contribution of assets and income, which is specifically adjusted and originates from financial accounting.

In fact, adequate financial information becomes necessary to complete the estimates or to better define their content, even if the methods based on cash flows or income are used. The basic idea is to recognize informational supremacy to actualize methodologies, even if in the family context a completion of the information obtained is desirable through the use of asset-based techniques [72, 73].

In this case, the main problem concerns the inability to find an active reference market, from which to draw useful information for the attribution of value to these intangible family resources. However, the values to be recorded in the financial statements originate from the amount of costs incurred by the company in the procurement phase [6]. In this regard, the writer believes that the method with autonomous estimate of goodwill is adaptable and succeeds better than any other to combine the contribution of assets and income with the business measurement, even in the family sphere:

$$
E V=K+(R-i ’ K)^{*} \text { a } n_{\rceil} i^{\prime}
$$

Where $\mathrm{EV}=$ equity value, $\mathrm{K}=$ adjusted net asset value using the complex asset based method, $\mathrm{R}=$ average normalized earnings, $i$ '=discount rate, $i$ " $=$ rate of return, and $n=$ time duration.

Firstly, the heritage assets must be corrected for the elements of non-transferable family contamination. As a consequence, all those appropriable assets and liabilities, regardless of their genesis, must be included.

In addition, the first element will be an incremented/decremented contribution of the so-called 'excess return'. It expresses the algebraic sum between normal income of the belonging sector, neglecting the familiar nature of the business organization and the prospective income obtainable from the company, examined on the basis of a going concern perspective.

In conclusion, the familiarity is to be counted among the various possible manifestations of intellectual capital and its business relevance will be linked to the consolidation in the business dynamics of family intangibles. In addition, the contribution of the so-called familiness to the creation of value is scrutinized by using techniques that are capable of grasping the separate capital and income contributions, having admitted that the family will have an indiscriminate impact on the company's life.

The innovative contribution of the present work consists of illustrating and proposing a possible model, such as evolution and adaptation of the aforementioned model, which considers the specific family dynamics present in the organizations under examination.

In this regard, there is a clear distinction between the business management and family management contribution to the business value creation process. Naturally in this process, the following situations must be considered:

1. The skills/knowledge, even if of family origin and linked to the companies, will contribute to the definition of the managerial assets/income;

2. The skills/knowledge, which are strictly linked to family members and therefore considered separable from the rest of the company.

From the formula indicated above, the family contribution, ascribable to the second category of resources indicated above, is to be broken down. In other words, taken as a reference, the method with autonomous estimate of goodwill (as a typical example of combined method), 'K assets' will have to be adjusted for non-transferable intangible assets and the value of 'goodwill' will have to be normalized, aimed at adjusting income of the contribution ascribable to the socalled unapproachable resources. In this regard, the following reference values should be considered:

$$
\mathrm{W}=\mathrm{K}+\left(\mathrm{R}-\mathrm{i}{ }^{\prime} \mathrm{K}\right) * \mathrm{a}_{7} \mathrm{i}^{\prime}-(\mathrm{SA}+\mathrm{SR})
$$

Where SA (surplus assets)=family genesis activities with legal autonomy and registered in the original balance sheet, as a surplus asset to be eliminated/corrected by the overall configuration of the capital; SR (surplus earnings)=income contribution of discounted family genesis. It is equal to ' $\mathrm{Rf}$ a $\mathrm{n}_{7} \mathrm{i}$ ', where ' $\mathrm{Rf}$ ' indicates the average income contribution of family genesis.

More specifically, the first quantity is of static genesis and is determined as the sum of assets. The second one instead is the resultant procedural of discounting the income contribution, ascribable to the family member.

Following these considerations, the following specific 
formula for the family firm is synthesizable:

$$
E V=(K-S A)+[(R-R f)-i ”(K-S A)]^{*} \text { a } n_{\eta} i '
$$

\section{References}

[1] Astrachan, J. H., Klein, S. B. and Smyrnios, K. X. (2005), The F-PEC Scale of Family Influence; Construction, Validation and Further Implication for Theory, Baylor University.

[2] Guthrie, J (2001), "The management, measurement and the reporting of intellectual capital", Journal of Intellectual Capital, Vol. 2, No. 1, pp. 27-41.

[3] Brenes, E. R., Madrigal, K. and Requena, B. (2011), "Corporate governance and family business performance", Journal of Business Research, Vol. 64, No. 3, pp. 280-285.

[4] Claver-Cortés, E., Zaragoza-Sáez, P. C., Molina-Manchón, H. and Úbeda-García M. (2015), "Intellectual capital in family firms: human capital identification and measurement", Journal of Intellectual Capital, Vol. 16, No. 1, pp. 199-223.

[5] Chrisman, J. J., Chua, J. H. and Steier, L (2005), "Sources and consequences of distinctive familiness: an introduction", Entrepreneurship: Theory and Practice, Vol. 29, No. 3, pp. 237-247.

[6] Villalonga, B. and Amit, R. (2006), "How do family ownership, control and management effect firm value?", Journal of Financial Economics, Vol. 80, No. 2, pp. 385-417.

[7] Szulansky, G. (2000), "The process of knowledge transfert: a diachronic analysis of stickiness", Organizational behavior and human decision processes, Vol. 82, No. 1, pp. 9-27.

[8] Dumay, J. (2009), "Intellectual capital measurement: a critical approach”, Journal of Intellectual Capital, Vol. 10, No. 2, pp. 190-210.

[9] Basco, R. (2013), "The family's effect on family firm performance. A model testing the demographic and essence approaches", Journal of Family Business Strategy, Vol. 4, No. 1, pp. 42-66.

[10] Kong, E. (2007), "The strategic importance of intellectual capital in the non profit sector", Journal of Intellectual Capital, Vol. 8 No. 4, pp. 721-731.

[11] Barry, B. (1975), "The development of organization structure in the family firm", Journal of General Management, Vol. 3, No. 1, pp. 42-60.

[12] Canibano, L, Covarsi, M. G and Sánchez, M. P. (1999), The value relevance and managerial implications of intangibles: a literature review, international symposium: measuring and reporting intellectual capital: experiences, issues, and prospects, OECD, 9-10 June, Amsterdam.

[13] Baron, R. A. and Markman, G. D. (2003), "Beyond social capital: The role of entrepreneurs' social competence in their financial success", Journal of Business Venturing, Vol. 18, No. 1, pp. 41-60.

[14] Nahapiet, J. and Ghoshal, S. (1998), "Social capital, intellectual capital, and the organizational advantage", Academy of Management Review, Vol. 23, No. 2, pp. 242-266.

[15] Simons, R. (2000), Performance measurement \& control system for implementing strategy, Prentice Hall, Upper Saddle River.

[16] Gomez-Mejia, L. R., Cruz, C., Berrone, P., \& De Castro, J. (2011), "The bind that ties: Socioemotional wealth preservation in family firms", Academy of Management Annals, Vol. 5, pp. 653-707.

[17] Berrone, P., Cruz, C., Gomez-Mejia, L. R. (2012), "Socioemotional wealth in family firms: Theoretical dimensions, assessment approaches, and agenda for future research, Family Business Review, Vol. 25, No. 3, pp. 258-279.

[18] Lansberg, I. S. (1983), "Managing Human Resources in Family Firms: The Problem of Institutional Overlap", Organizational Dynamics, Vol. 12, No. 1, pp. 39-46.

[19] Habbershon, T. G., Williams, M. L. (1999), “A resource based framework for assessing the strategic advantages of family firms", Family Business, Vol. 12, pp. 1-25.

[20] Frank, H., Luegerb, M., Noséc, L. and Suchy D. (2010), “The concept of "Familiness": Literature review and systems theory-based reflections", Journal of Family Business Strategy, Vol. 1, No. 3, pp. 119-130.

[21] Levinson, H. (1971), "Conflicts that Plague Family Business", Harvard Business Review, Vol. 49, No. 2, pp. 90-98.

[22] Chandler, A. (1962), Strategy and Structure: Chapters in the History of the American Industrial Enterprise, The Mit Press, Cambridge.

[23] Foss, N. and Knudsen, T. (2003), "The resourced-based triangle: toward a sustainable explanation of competitive advantage", Managerial and Decision Economics, Vol. 24, No. 4, pp. 291-308.

[24] Barnes, L. B. and Hershon, S. A. (1976), "Transferring power in the family business", Harvard Business Review, Vol. 54, No. 4, pp. 105-114.

[25] Charbel, S., Elie, B. and Georges, S. (2013), "Impact of family involvement in ownership management and direction on finanzcial performance of the Lebanese firms", International Strategic Management Review, Vol. 1, No. 1-2, pp. 30-41.

[26] Riahi-Belkaoui, A. (2003), "Intellectual capital and firm performance of US multinational firms: a study of the resource-based and stakeholder views", Journal of Intellectual Capital, Vol. 4, No. 2, pp. 215-226.

[27] Ward, J. (1990), Di padre in figlio: l'impresa di famiglia, come preparare il passaggio generazionale e assicurare continuità e prosperità alle aziende familiari, Franco Angeli, Milan.

[28] Wong, K. Y. and Apinwall, E. (2004), "Characterizing knowledge management in the small business environment", Journal of Knowledge Management, Vol. 8, No. 3, pp. 44- 61.

[29] Stewart, T. A. (1997), Intellectual Capital: The New Wealth of Organizations, Doubleday-Currency, New York.

[30] Kaplan, R. and Norton, D. (2004), Strategy Maps - converting intangibles assets into tangible outcomes, Harvard Business School Press, Boston, MA.

[31] Beckhard, R. and Dyer, W. G. Jr. (1983), "Managing continuity in the family-owned business", Organizational Dynamics, Vol. 12, No. 1, pp. 5-12. 
[32] Turco, M. and Fasiello, R. (2011), "La conservazione del valore nelle imprese familiari: un modello di gestione del passaggio generazionale basato sulle risorse intangibili", Electronic Journal of Management, Vol. 2, pp. 1-41.

[33] Johanson, U. (2005), A human resources perspective on intellectual capital, in Marr, B. (Eds), Perspectives on Intellectual Capital, Elsevier, Burlington, MA, pp. 96-105.

[34] Zellweger, T., Eddleston, K., and Kellermanns, F. W. (2010), 'Exploring the concept of familiness: introducing family firm identity', Journal of Family Business Strategy, Vol 1, No 1, pp. 54-63.

[35] Adams, R. B., Almeida, H. and Ferreira, D. (2009), "Understanding the relationship between founder-CEOs and firm performance", Journal of Empirical Finance, Vol. 16, No. 1, pp. 287-302.

[36] Zellweger, T., Nason, R. S., and Nordqvist, M. (2011), 'For Longevity of firms to transgenerational entrepreneurship of families: introducing family entrepreneurial orientation', Family Business Review, Vol 25, No 2, pp 136-155.

[37] Grant, R. M. (1991), "The Resource-Based Theory of Competitive Advantage: Implications for Strategy formulation “, California Management Review, Vol. 33, No. 3, pp. 114135 .

[38] Chua, J. H., Chrisman, J. J. and Sharma, P. (1999), "Defining the family business by behavior", Entrepreneurship theory and practice, Vol. 23, No. 4, pp. 19-39.

[39] Roos, G., Bainbridge, A. and Jacobsen, K. (2001), "Intellectual Capital Analysis as a strategic tool", Strategy and Leadership Journal, Vol. 29, No. 4, pp. 21-26.

[40] Pirozzi M. G. and Ferulano G. P. (2016), "Intellectual capital and performance measurement in the healthcare organizations. A new integrated model", Journal of Intellectual Capital, Vol. 17, No. 2, pp. 320-350.

[41] Cabrera-Suarez, K., De Saa-Pèrez, P. and Garcia-Almeida, D. (2001), "The Succession Process from a Resource and Knowledge-Based View of the Family Firm", Family Business Review, Vol. 14, No. 1, pp. 37-48.

[42] Gibb Dyer Jr., W. (2006), "Examining the "Family Effect" on Firm Performance", Family Business Review, Vol. 19, No. 4, pp. 253-273.

[43] Kaplan, R. S. and Norton, D. P. (1992), "The Balanced Scorecard, Measures That Drive Performance", Harvard Business Review, Vol. 70, No. 1, pp. 71-79.

[44] Polanyi, M. (1967), The Tacit Dimension, Anchor Day Books, New York.

[45] Nelson, R. R. and Winter, S. G. (1982), An Evolutionary Theory of Economic Change, Belknap Press/Harvard University, Cambridge, MA.

[46] Kogut, B. and Zander, U. (1992), "Knowledge of the firm, combinative capabilities and replication of technology", Organization Science, Vol. 3, No. 3, pp. 383-397.

[47] Perricone, J. P., Earle, J. R. and Taplin, I. M. (2001), "Patters of succession and continuity in family-owned businesses: study o fan ethnic community", Family Business Review, Vol. 14, No. 2, pp. 105-121.

[48] Jensen, M. and Meckling O. (1976), "Theory of the firm: managerial behavior, agency costs and ownership structure", Journal of Financial Economics, Vol. 3, No. 2, pp. 305-360.

[49] Davis, J. H., Schoorman, D. F. and Donaldson L. (1997), "Towards a stewardship theory of management", Academy of Management Review, Vol. 22, No. 1, pp. 20-47.

[50] Eddlestone, K. A. and Kellermanns, F. W. (2007), "Destructive and productive family relationship: a stewardship theory perspective", Journal of Business Venturing, Vol. 22, No. 4, pp. 545-565.

[51] Fama, E. and Jensen, M. (1983), "Separation of ownership and control", Journal of Law and Economics, Vol. 26, No. 2, pp. 301-325.

[52] Eddleston, K., Kellermanns, F. W. and Sarathy, R. (2008), "Resource configuration in family firms: Linking resources, strategic planning and environmental dynamism to performance", Journal of Management Studies, Vol. 45, No. 1, pp. 26-50.

[53] Miller, D., Le Breton-Miller, I. and Scholnick, B. (2008), "Stewardship vs Stagnation: an empirical comparison of small family and non-family business", Journal of Management Studies, Vol. 45, No. 1, pp. 51-78.

[54] Sirmon, D. G. and Hitt, M. A. (2003), "Managing resources: linking unique resources, management, and wealth creation in family firms", Entrepreneurship Theory and Practice, Vol. 27, No. 4, pp. 339-358.

[55] Maditinos, D., Chatzoudes, D., Tsairidis, C. and Theriou, G. (2011), "The impact of intellectual capital on firms' market value and financial performance", Journal of Intellectual Capital, Vol. 12, No. 1, pp. 132-151.

[56] Westhead, P. and Howorth, C. (2006), "Ownership and management issues associated with family performance and company objectives", Family Business Review, Vol. 19, No. 4, pp. 301-316.

[57] Poutziouris, P., Savva, C. S. and Hadjielias, E. (2015), "Family involvement and firm performance: Evidence from UK listed firms", Journal of Family Business Strategy, Vol. 6, No., pp. 14-32.

[58] Memili, E. (2015), "Performance and Behavior of Family Firms", International Journal of Financial Studies, Vol. 3, No. 3 , pp. 423-430.

[59] Gonzáleza, M., Guzmánb, A. and Pomboa, M. C. (2012), "Trujillo A., Family firms and financial performance: The cost of growing", Emerging Markets Review, Vol. 13, No. 4, pp. 626-649.

[60] Greco, G., Ferramosca, S. and Allegrini, M. (2014), "Exploring intellectual capital in family firms. An empirical investigation", International Journal Learning and Intellectual Capital, Vol. 11, No. 2, pp. 91-106.

[61] San Martin Reyna, J. M. and Duran-Encalada Jorge, A. (2012), "The relationship among family business, corporate governance and firm performance: Evidence from the Mexican stock exchange", Journal of Family Business Strategy, Vol. 3, No. 2, pp. 106-117.

[62] Pugliese, A. (2006), L'informativa di bilancio nelle imprese familiari, in Viganò, E. (Eds), La sensibilità al valore nell'impresa familiare, Cedam, Padua, pp. 143-167. 
[63] Kujansivu, P. and Lönnqvist, A. (2007), "Investigating the value and efficiency of intellectual capital", Journal of Intellectual Capital, Vol. 8, No. 2, pp. 272-287.

[64] Firer, S. and Williams, S. M. (2003) 'Intellectual capital and traditional measures of corporate performance', Journal of Intellectual Capital, Vol. 4, No. 3, pp. 348-360.

[65] Giuliani, M. and Marasca, S. (2011), "Construction and valuation of intellectual capital: a case study", Journal of Intellectual Capital, Vol. 12, No. 3, pp. 377-391.

[66] Marias Gama, A. P., Galvao, M. and Manuel, J. (2012), "Performance, valuation and capital structure: survey of family firms", Corporate Governance, Vol. 12, No. 2, pp. 5980 .

[67] Agliata, F. (2016), Una visione critica delle interazioni esistenti tra famigliarità e misura del valore economico, in Anselmi, L. and Lattanzi, N. (Eds), Il family business made in Tuscany, FrancoAngeli, Milan, pp. 237-269.

[68] Astrachan, J. H. and Jaskiewicz, P. (2008), "Emotional returns and emotional costs in privately held family business: advancing traditional business valuation", Family Business Review, Vol. 21, No. 2, pp. 139-149.
[69] Reilly, R. F. (2006), "Valuation adjustments in family law business valuations", American Journal of Family Law, Spring, pp. 21-32.

[70] Cuccurullo, C. (2006), Le valutazioni comparative, in in Viganò E. (Eds), La sensibilità al valore nell'impresa familiare, Cedam, Padua, pp. 307-331.

[71] Hagan, J. M. (2011), “An application of business valuation techniques for closely-held family owned", Construction accounting and taxation, Vol. 21, No. 6, pp. 39-45.

[72] Sraer, D. and Thesmar, D. (2007), "Performance and behavior of family firms: Evidence from the French stock market", Journal of the European Economic Association, Vol. 5, No. 4, pp. 709-751.

[73] Tiscini, R. (2006), Occasione di valutazione economica del Family Business. Profili introduttivi. Le operazioni straordinarie con non familiari, in. Vigano E. (Eds), La sensibilità al valore nell'impresa familiare, Cedam, Padua, pp. 235-271. 